\title{
MARKET SHARE ISLAMIC BANKING IN INDONESIA
}

\author{
Zulfikar Hasan \\ Academy of Islamic Studies University of Malaya (APIUM) Malaysia \\ Department of Syariah and Economics \\ Email: zulfikarhasan61@gmail.com
}

\begin{abstract}
At the end of 2016, the Islamic banking market share stood at 356.5 trillion Indonesian rupiahs ( $\$ 26.7$ billion), equivalent to 5.03 per cent of the total banking sector's assets. Islamic banking assets have risen faster year-on-year compared to conventional banking, registering a growth of 8.8 per cent in 2015 and 20.3 per cent in 2016. The performance of the Islamic banking industry in Indonesia has yet to satisfy the public's expectations. Although with a market of more than 200 million Muslims, Islamic banks in Indonesia still face difficulties luring more customers and increasing their assets. For three consecutive years, the market share of the sharia banks in the country stood still at less than 5 per cent. According to the Global Advisors Islamic Finance Outlook Report for 2016, no Indonesian Islamic banks were ranked in the top five largest banks based on assets in Southeast Asia. This is an alarming situation for the industry and regulators. Thus, it evokes a question: Is the market becoming saturated for Islamic finance? This study aims to determine the factors that affect the market share of Islamic banks in Indonesia. With a focus on four main items, Islamic banking regulations, Islamic banking inclusion and literacy are still low from conventional banks, Islamic banking still does not have sufficient capital and the number and quality of Human Resources (HR) that are inadequate. This study uses an analytical descriptive study is to describe and analyzed data obtained based on primary and secondary data. While the method used is normative and focused on the study of literature, which is then analyzed qualitatively juridical.
\end{abstract}

Keywords: Islamic Banking, Market Share, Islamic Industry, Human Resources.

\section{INTRODUCTION}

The development of the Islamic banking system in Indonesia began introduced in 1992 with the establishment of PT Bank Muamalat Indonesia (BMI). The existence of a profit sharing system in Islamic banks initially not received greater attention from the government at that time had many emerging due to the bank with interest rate system rather than sharing system. The legal basis for operations of banks which use sharia system, when it is only based on one verse of "bank sharing system" to the Law 7 of 1992; without explaining the details of the legal basis of sharia and the types of businesses that are allowed. Banking Authority at that time was controlled by Bank Indonesia, and as of December 31, 2013 the regulation and supervision of banks do FSA.

On the global market, Indonesia entered into the top ten countries with the largest Islamic financial indexes in the world. However, the Islamic finance growth cannot keep pace with conventional finance. It can be seen from the 
market (market share) of Islamic finance as a whole remains below 5\%. Awareness of the central government in the regulation governing Islamic banking, Islamic financial plays such an important role to see further how the future prospects of Islamic banking. In addition to the regulations that fully support Islamic banking can also be seen in the increase of banks performance either BUS (Islamic Banks) and UUS (Sharia) that can release products of innovative Islamic banking products and latest.

Things that need to be done in accelerating the growth of the Islamic finance in Indonesia, especially Islamic banking is conducting various programs to solve various problems both at national and regional levels. Common problems faced by Islamic banking Islamic products such limitations; limited access to Islamic financial products; the low level of financial literacy and the level of utility sharia Islamic financial products; limited human resources; the need to optimize coordination with stakeholders; as well as the need for financial services policies are aligned and can support each other throughout the development of Islamic banking sector.

Contribution we can give as a researcher is to provide knowledge to all of us, especially to academics engaged in the world Islamic economics and Islamic banking that the market share of Islamic banking in Indonesia has an important role in seeing the growth in the sector with regard, in addition to giving little thought market share of Islamic banking in Indonesia.

This article discusses the market share of Islamic banking in Indonesia why it is still below 5\%. With a focus on five main items, namely the regulation of Islamic banking, Islamic banking inclusion and literacy are still lower than conventional banks, Islamic banking still do not have adequate capital and the number and quality of Human Resources (HR) is inadequate. A conclusion will be made to show how market share of Islamic banking in Indonesia.

\section{LITERATURE REVIEW}

Research on the market share of Indonesian Islamic banking has been widely researched by academics both in the domestic and foreign. For this study, we saw growth market share in Indonesia is not only influenced by the overall financial performance of Islamic banks in Indonesia, but also influenced by external factors of the bank itself. Research made by (Saputra 2014) it can be concluded that by data analysis and discussion that has been concluded that the Return On asset(ROA), Capital Adequacy Ratio (CAR), Financing to Deposit Ratio (FDR) positive significant effect on the market share of Islamic Banking in Indonesia. As for Non Performing Financing (NPF) and Operating Efficiency Ratio (REO) a significant negative effect on the market share of Islamic banking in Indonesia, thus causing the entire hypothesis is accepted. The results of this study imply that the management needs to maintain the performance of Islamic banking and financial health, especially to increase ROA, CAR and FDR in order to increase market share and lower NPF and REO. With the support of supervision and oversight from Bank Indonesia and Financial Services Authority (FSA) is appropriate and the selection of appropriate strategy anyway to increase performance and health bank Sharia, is expected to boost the growth of the market share of Islamic banking in Indonesia. 
Further research made by (Rahman 2016). In the early observations of variable ROA (Operating Expenses Operating Income) has a very dominant influence at all compared with other variables. While at the end of the observation, the variable NPF (Non Performing Financing) has a variance that is very dominant in influencing the market share of Islamic banks So we can conclude that, the variable BOPO dominant in influencing market share of Islamic banks in the long term, while the CAR (Capital Adequacy Ratio) in affect the market share of Islamic banking in the short term.

In addition to internal factors of the bank itself, there are several external factors that affect the market share of Islamic banking in Indonesia, a study made by (Alhamid 2019) find that factors such as HR (Human Resources) constitute the most prominent of which influenced the development of Islamic banking in Indonesia. Be sides the lack of understanding of practitioners of Islamic banks, both the business and the development of sharia. In other words unmet qualified human resources in the field of Islamic economics, Islamic banking so that in practice often deviates from Islamic principles. Second, supply oriented. Practitioners can only explain what they knew but could not answer the questions asked by the public.

Acceleration of the growth of Islamic banking can also be done through the implementation of sharia good governance and structured. The research was made by (Abubakar and Handayani 2017). Implementation of good governance, consistent and sustainable addition to aiming to protect the interests of stakeholders, as well as improve adherence to Islamic principles. Adherence to Islamic principles that will be the difference between the scope, urgency, and the application of governance in Islamic banking. Islamic principles will now be seen from the basic principle of Islamic banking operations where the bank's capital and savings channeled through sharing based financing transactions, commissions and margins. Other than that, Islamic banks have a social function as a reservoir of zakat and also lenders virtue/bailouts (qard and qardulhasan) are not recognized in conventional banking. So the sharia good governance will ensure the smooth running of the transaction on the run in the Islamic banking and have an influence in the development of the market share in Indonesia.

Depositor Funds indicators, ROA, NPF and FDR jointly affect the increase in the market share of Islamic banking in Indonesia. Results of research made by (Purboastuti et. al. 2015). Variable Third Party Funds significant positive effect on the market share of Islamic banking in Indonesia, meaning if there is an increase in the TPF will affect the increase in the market share of Islamic banking in Indonesia. ROA significant positive effect on the market share of Islamic banking in Indonesia, meaning if there is an increase in ROA will affect the increase in the market share of Islamic banking in Indonesia. Variable NPF significant negative effect on the market share of Islamic banking in Indonesia, means that if an increase in the NPF will lower the market share of Islamic banking in Indonesia. Variables FDR positive effect but not significant to the market share of Islamic banking in Indonesia, meaning if there is an increase in the FDR then there is no effect on the market share of Islamic banking. If there is any effect, FDR had very little effect on the market share of Islamic banking in Indonesia. Variable Ratio significant negative effect on the market share of Islamic banking in Indonesia, meaning if there is an increase in the ratio will decrease the market share of 
Islamic banking in Indonesia. means that if an increase in the FDR then there is no effect on the market share of Islamic banking. If there is any effect, FDR had very little effect on the market share of Islamic banking in Indonesia. Variable Ratio significant negative effect on the market share of Islamic banking in Indonesia, meaning if there is an increase in the ratio will decrease the market share of Islamic banking in Indonesia. Means that if an increase in the FDR then there is no effect on the market share of Islamic banking. If there is any effect, FDR had very little effect on the market share of Islamic banking in Indonesia. Variable Ratio significant negative effect on the market share of Islamic banking in Indonesia, meaning if there is an increase in the ratio will decrease the market share of Islamic banking in Indonesia.

Once again the research made by (Hamzah 2008), get that improved competitiveness can run when classical problems in Islamic banking in the completed such as the human resources that are less professional, the product is still less attractive, socialization which has not been much to contribute, the quantity is limited and regulations yet to be passed. Still in the framework of the internal reinforcement and the foundation of the development of Islamic banking. The quality competitiveness is not only based on ideals, but also demands rationality. The market share of Islamic banking is rahmatan lil 'Alamin, for the whole of nature without being confined by idealistic customer segmentation. Therefore, facts are needed that are able to show the superiority of this Islamic banking system, Indonesia can reflect and learn the advanced countries such as Japan, Singapore and the United Kingdom are already interested in the concept of management of Islamic banks, as the majority of customers who were there are customers who rationalist. It indirectly proves the universality of the banking system which is based on the teachings of the Islamic religion.

\section{RESEARCH METHODS}

This study uses analytical descriptive study is to describe and analyzed data obtained based on primary and secondary data. While the method used is normative and focused on the study of literature, which is then analyzed qualitatively juridical.

\section{THE CURRENT STATE OF MARKET SHARE ISLAMIC BANKING IN INDONESIA}

Indonesia's Islamic banking continues to post strong growth of its assets, financing, and deposits. All performance indicator of Islamic banking industry improves compared to previous year. 
Picture 1

Current Exposure

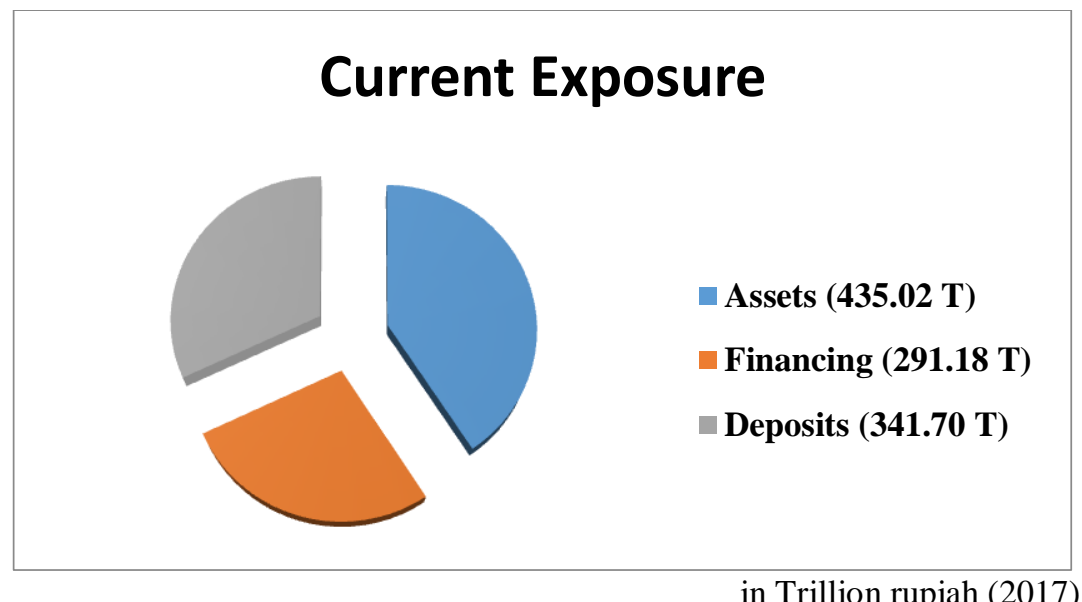

Data from OJK until August 2017, total Indonesian Islamic financial assets (excluding Sharia Shares) reached Rp 1,048.8 trillion, consisting of Islamic Banking assets of Rp 389.74 trillion, Syariah IKNB Rp 99.15 trillion, and Islamic Capital Market Rp 559,59 trillion. The sharia banking industry currently consists of 13 sharia public banks, 21 sharia unit banks, and 167 sharia BPRs, which have total assets of $\operatorname{Rp} 389.7$ trillion or 5.44 percent of total national banking assets.

Picture 2
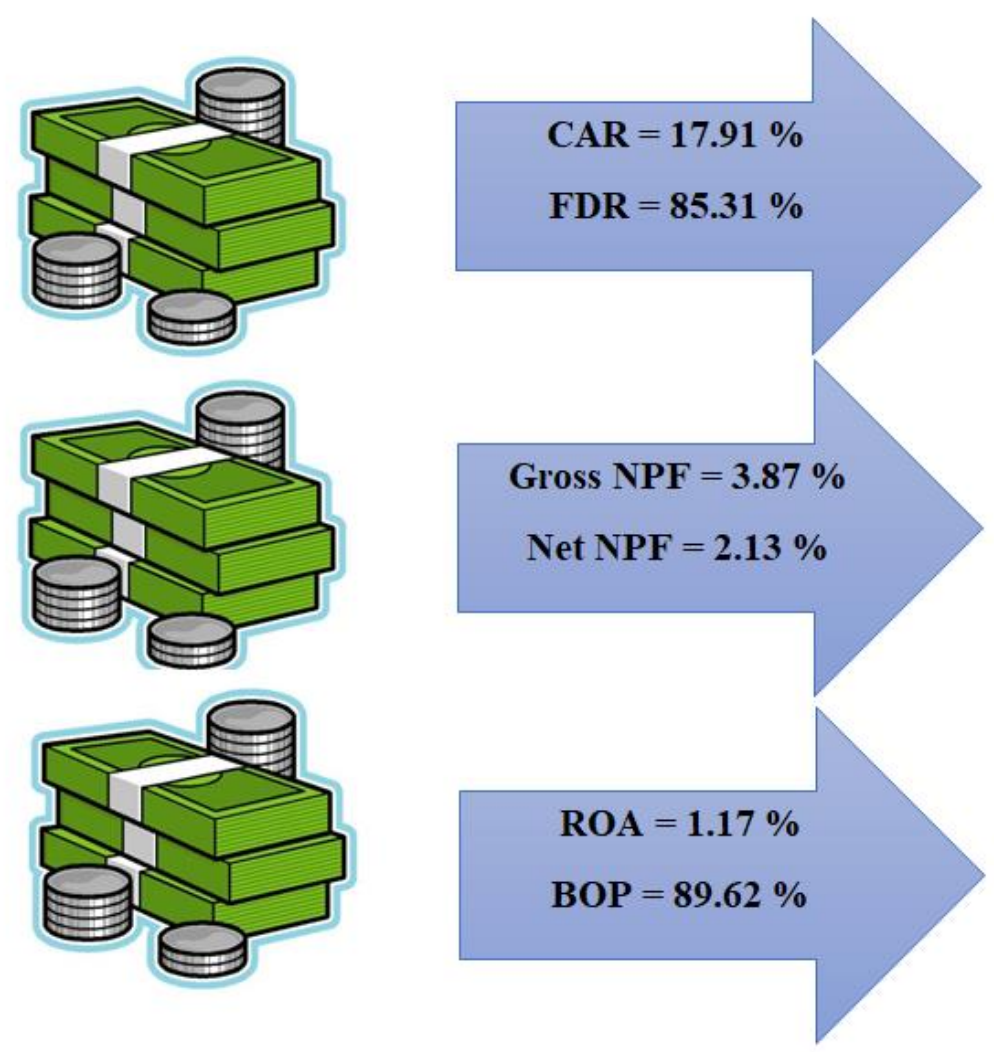
Asset Growth of Sharia Banking Industries (2013-2017)

in trillion rupiah

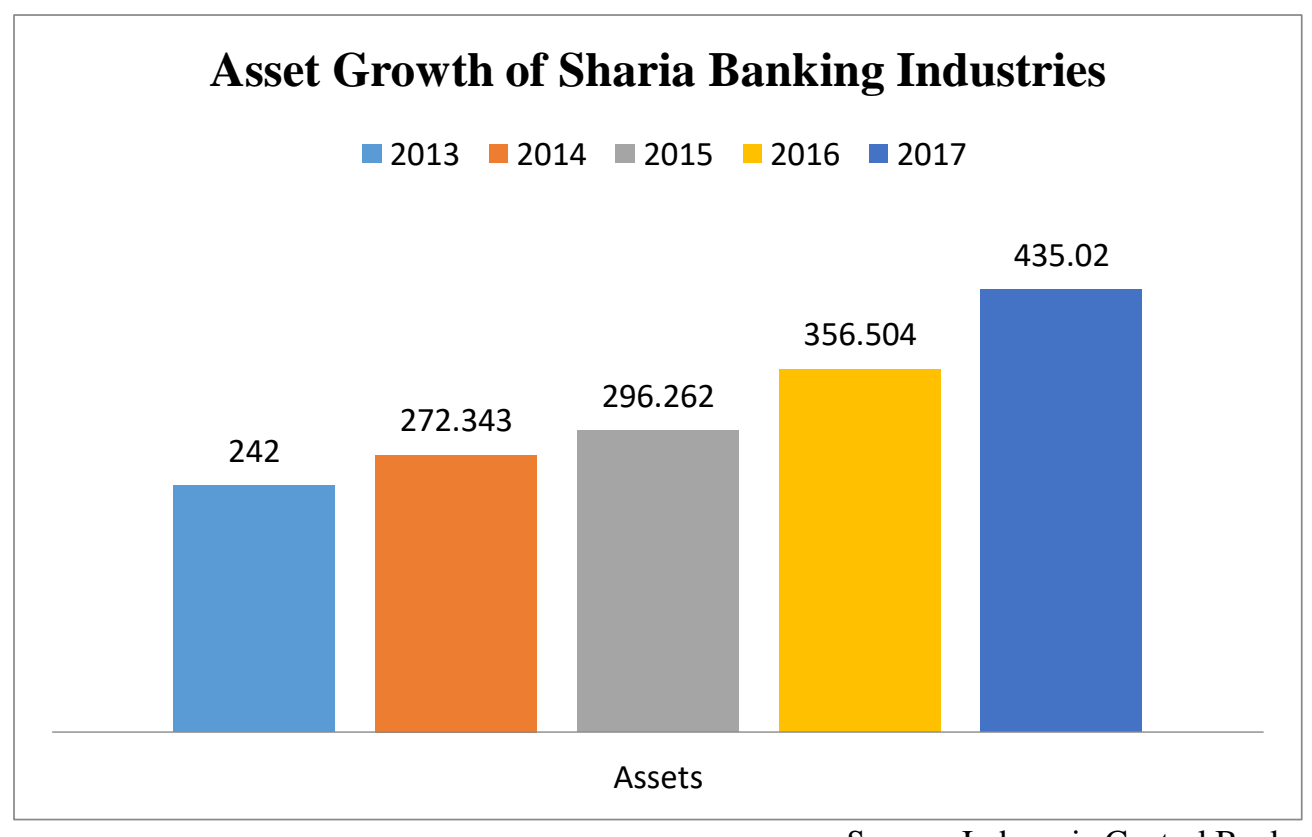

The increase in the number of Shariah public banks is rapidly in Indonesia, where in 1992 by Bank Muamalat (only one bank) and in the year 2017 developed into totaled 13 Shariah public banks (Bank Muamalat Indonesia, Bank Syariah Mandiri, Bank Mega Syariah, Bank BRI Syariah, Bank Syariah Bukopin, Bank BNI Syariah, Bank Jabar Banten Syariah, BCA Syariah, Bank Victoria Syariah, Maybank Syariah Indonesia, Bank Panin Syariah, Bank Tabungan Pensiunan Nasional Syariah, Bank Aceh), and 21 Islamic business units and 167 Islamic people's credit banks. The average asset growth (year-on-year) has reached 25.02 percent in the last five years. Nevertheless, the rate of growth of Islamic banking assets experienced a slowdown. Where the asset growth of Shariah banking based on statistics published by the Central Bank of Indonesia, recorded growth of Islamic banking assets continued to increase. The increase of asset sharia bank industries (full pledge sharia bank and subsidiary sharia bank) can be shown in the above graphic the growth of sharia industries during 2013-2017.

\section{DISCUSSION AND ANALYSIS}

Based on what I mentioned above, that I have formulated 5 main points for my analysis and things that hinder the market share of Islamic banking which is still around 5-6\% even though sharia banking in Indonesia has been established for more than 30 years. The main points are: Islamic banking regulations, Islamic banking inclusion and literacy are still low from conventional banks, Islamic banking still does not have sufficient capital, and the number and quality of Human Resources (HR) that are inadequate. 


\section{Regulation Of Islamic Banking in Indonesia}

Forms of Islamic banking operated in Indonesia before the state began legislating for it. By the late 1980s, several non-bank financial institutions offered Islamic profit-share contracts, although they lacked a formal legal regulatory framework for doing so. When Indonesia's first official Islamic bank, Bank Muamalat Indonesia, was established on 1 November 1991, no banking regulations were in place to support it. Indeed, the banking legislation at that time defined "bank revenue" as "revenue from interest" precisely the notion prohibited by conservative interpretations of ribā.

To encourage the growth of Islamic banking due to the insistence of the grass root community in Indonesia, the government has amended of Government regulations number 7 (1992) as outlined in Law number 10 (1998) which confirms the existence of Islamic banking in Indonesia operating in a dual banking system. This policy has provided an opportunity for conventional commercial banks to provide sharia services through the Islamic window mechanism by first establishing (UUS). As a result, many conventional banks took part in providing sharia services to their customers, which were facilitated by the office chaneling concept regulated in Bank Indonesia Regulation number 8/3/PBI/ 2006. To provide sharia services via office chaneling, conventional commercial banks that already have UUS at their head office, no longer need to open a new branch / subbranch office but simply open a sharia counter in a conventional branch / subbranch office. Post Law number 10 (1998), came the BUS Bank Syariah Mandiri (BSM) which was the result of the acquisition and conversion of PT. Bank Susila Bakti by PT. Bank Mandiri (Persero) Tbk. In addition, Bank Mega has also carried out the same process by forming PT. Bank Syariah Mega. While other banks, such as PT. Bank Rakyat Indonesia (Persero) (Tbk), PT. Bank Negara Indonesia (Persero) Tbk, Bank Permata still operates as UUS at that time.

To ensure compliance with sharia banking products, a number of fatwas issued by the National Sharia Board Indonesian Council Of Ulema (DSN-MUI), including Fatwa number 04/DSN-MUI/IV/2000 concerning Mudharabah financing, Fatwa number 08/DSN/MUI/IV/2000 concerning Musyarakah financing. In addition, Law number 21 of 2008 has been regulated to provide opportunities for foreign citizens and / or foreign legal entities to establish or own BUS in partnership with Indonesian citizens and or Indonesian legal entities. Based on Islamic Banking Statistics issued by BI (August 2017), Islamic banking has 13 Islamic banks, 21 Islamic business units and 167 Islamic people's credit banks.

Legal Framework and regulation for Sharia Banking in Indonesia:

1. Law nnumber 21 of 2008 on Sharia Banking

2. Shariah Banking rules and SEBI PBI (Indonesian Bank Circular and Indonesian Bank Regulations)

3. Besides that there are also fatwas from Indonesia Ulema Council Fatwas.

Although many aspects of Islamic banking have been regulated, there are still aspects of the Islamic banking business that have not been regulated in the Sharia banking legal framework adn regulations. besides that the Indonesian government must be more responsive and accommodating in providing a legal framework for Islamic banking operations of Islamic banking such as in Malaysia whose market share has reached 25 percent. Based on the above facts, it is clear 
that the delay in the growth of Islamic banking in Indonesia is because it is not supported by Islamic banking regulations in the early emergence of Islamic banks in Indonesia. Therefore, Islamic banking regulations must always be amended and promulgated to respond to the need for legal certainty governing the Islamic banking industry in the future. Not only that, Indonesia also does not yet have a special body to coordinate Islamic financial institutions, including Islamic banks. This is what makes Islamic banks in Indonesia still losing, not only with conventional banks in Indonesia, but also Islamic banks in other countries. Compared to Malaysia, we are from buttom up, Malaysia from top down. Because in Malaysia there has also been a coordinating institution, they have MIFC (Malaysia International Islamic Financial Center). whereas we still don't have institutions like Malaysia.

But in 2016 the government has established a National Islamic Finance Committee (KNKS) through Presidential Regulation number 91 of 2016 concerning the National Islamic Finance Committee. The establishment of the National Islamic Finance Committee (KNKS) is a manifestation of the government's commitment to develop sharia economy and finance in Indonesia seriously by involving all stakeholders.

\section{Islamic Banking Inclusion and Literacy}

Banking sector has an important role in granting access to unbankable people. the Indonesian banking sector has grown from year to year. This can be seen from the increase in the number of branch offices, Depositor Funds (DPK) collected, and loans channeled by banks. Along with the development of the banking sector, banking services must also be evenly distributed throughout Indonesia. Banking services must reach people in all provinces in Indonesia.

An inclusive financial system must have users as much as possible, therefore an inclusive financial system must reach widely among users. The proportion of the population that has a bank account is a measure for banking penetration.

THE latest Global Findex (Financial Inclusion Index) database released by the World Bank finds that Indonesia has made the most progress, across East Asia and the Pacific, in bringing its citizens into the formal financial system in the past three years. Almost fifty percent $(48.9 \%)$ of the adults in Indonesia now own a bank account, reflecting a true turning point in the country's journey to boost financial inclusion. This also registers a marked improvement from its $36 \%$ of account ownership in 2014 and 20\% in 2011. Between 2014 and 2017, Indonesia also saw the biggest account ownership increase of any developing economy in the East Asia and Pacific region. Indonesia also boasts a strong use of accounts for saving, registering 10 percentage points higher than the developing world average. Forty-two percent of account owners save at a formal financial institution such as a bank or microfinance institution.

Composition of Islamic Bank Third Party Funds (TPB) in Indonesia developed rapidly along with the development of Islamic banks in Indonesia. Significant developments in this TPF can also be seen in the 2017 Sharia Banking Statistic issued by the Financial Services Authority (OJK). 
Table 1

Number of Customer of Financing and Third Party Fund Sharia (TPF) Commercial Bank dan Sharia Business Unit

\begin{tabular}{|l|c|c|c|c|}
\hline Type & $\mathbf{2 0 1 4}$ & $\mathbf{2 0 1 5}$ & $\mathbf{2 0 1 6}$ & $\mathbf{2 0 1 7}$ \\
\hline Third Paty Fund & $11,444,013$ & $14,761,002$ & $18,521,091$ & $21,609,703$ \\
\hline $\begin{array}{l}\text { Financing. } \\
\begin{array}{l}\text { Receivables/Acceptables, } \\
\text { Ijarah and Salam }\end{array}\end{array}$ & $3,175,910$ & $3,401,887$ & $3,801,121$ & $4,519,948$ \\
\hline
\end{tabular}

From the table 1 above we can see that the development of the number of Third Party Funds (TPF) in Islamic Banking has increased from year to year. As in 2014 the number of TPF 11,444,013 increased sharply in 2017 amounting to 21,609,703. While talking about the amount of funds from Third Party Funds also experienced a significant increase as the number of customers increased from year to year, as in the graph below.

\section{Picture 4 \\ Third Party Funds for Islamic Banking (2014-2017)}

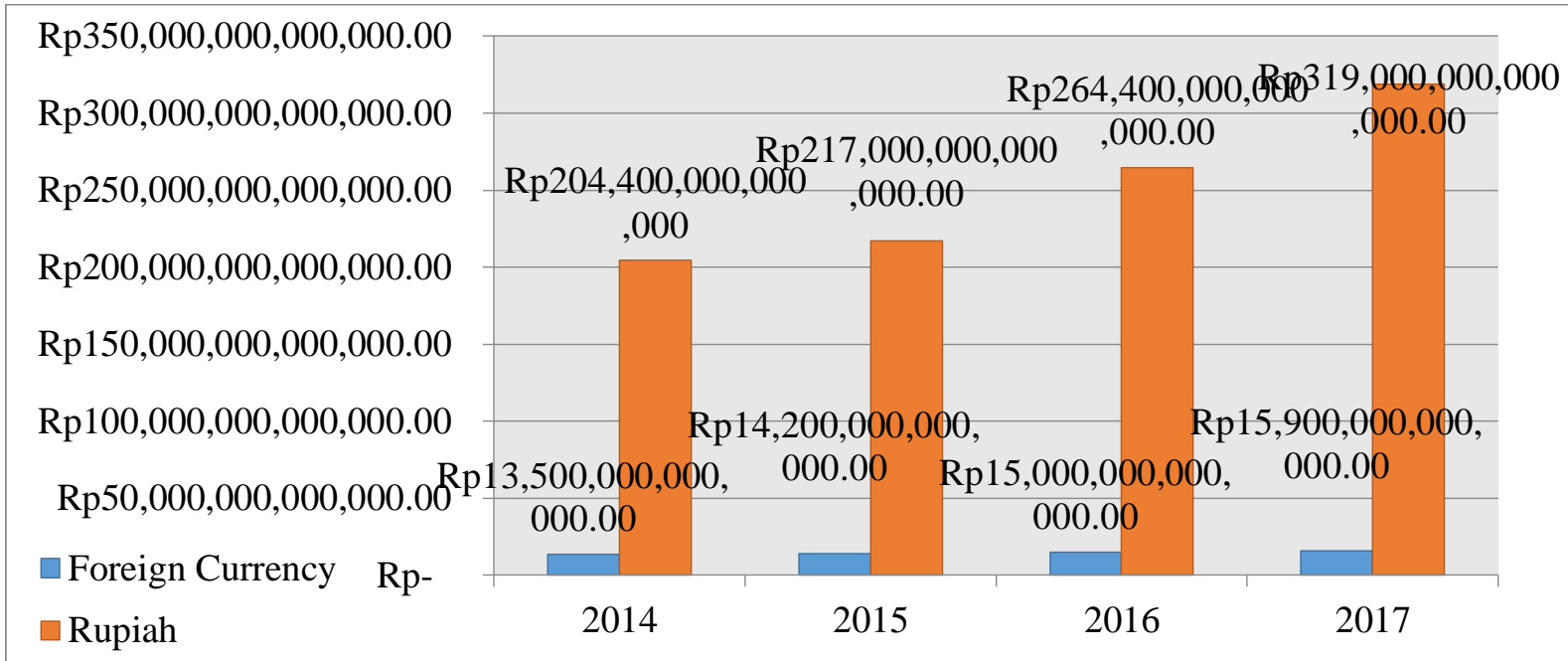

Source : Financial Services Authority (OJK) 2017 Authors processed

Indonesian Islamic banking Third Party Funds (DPK) have grown to Rp 334.9 trillion at the end of 2017 compared to 2014. The amount consists of IDR 319 trillion rupiah and IDR 15.9 trillion foreign exchange.

Picture 5

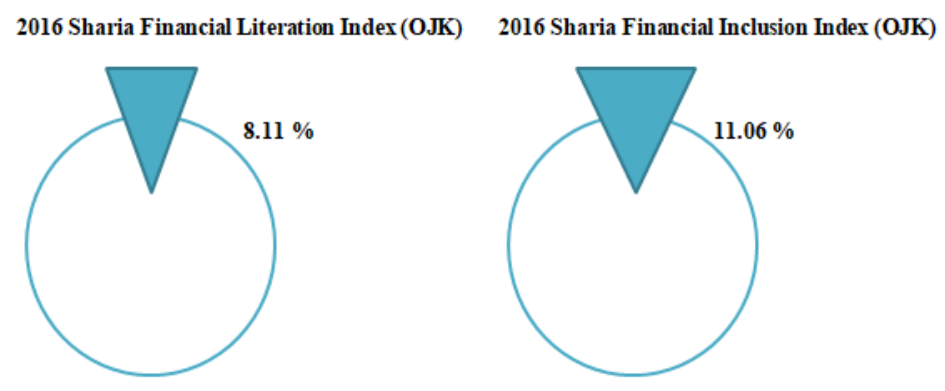


Even though data on the number of customers and Third Party Funds (DPK) has increased from year to year, in 2016 for the first time the Financial Services Authority (OJK) conducted a survey to measure the level of literacy and inclusion of Islamic finance. As a result, the Islamic financial literacy index amounted to 8.11 percent and the Islamic financial inclusion index was 11.06 percent. This means that the public's understanding of Islamic financial services and products is still low. By sector, the highest Islamic financial literacy index is still in the banking sector with 6.63 percent. Whereas banking syariah financial inclusion reached 9.61 percent.

Although the level of literacy and inclusion of Islamic finance in Indonesia is still low when compared to conventional finance, there are a number of things we can do to encourage a percentage increase in the field of Islamic finance especially Islamic Banking. Islamic banking needs to increase literacy and inclusion in Islamic finance. The main thing seen to achieve the inclusion and literacy index is more on the understanding of Maqasid Syariah. This is the main agenda, especially in Islamic banking because considering our Maqasid Syariah literacy is very low. This must be done, if not like that, the share of Islamic banking will not be significant. In addition, there are some Muslim communities who do not all understand the difference in interest and profit sharing. Even though it is very different in contract.

First, the Sharia People's Financing Bank (BPRS) continues to develop Islamic financial inclusion to the community that has not been in contact with the bank. This is the first target that can be done in the future. That way, BPRS can play a role in overcoming poverty and inequality and improving people's lives. Second, Islamic finance education and literacy must continue to be developed by banks. Can work with Islamic boarding schools, community leaders, both in villages and urban villages to disseminate information to the community. Third, this inclusion can be done as long as there is assistance or monitoring of the people who are the target of this sharia financial dissemination.

in addition, the author will also provide the results of data from the Financial Services Authority regarding sectoral literacy and inclusion indices as below.

\section{Picture 6}

Index Literation and Inclusions Islamic Finance 2016

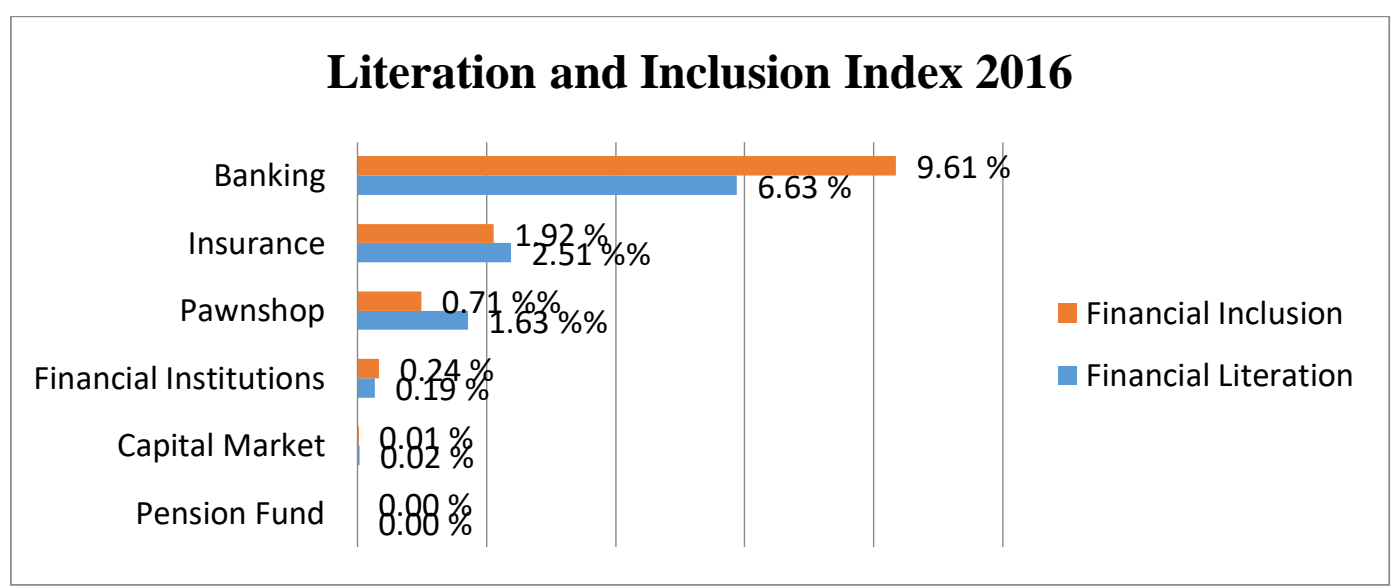

Source: Financial Services Authority (OJK) 2017 authors processed 
Islamic banking is still the financial services institution that is most familiar with the community. This can be seen from the highest literacy index, which is 6.63 percent with an inclusion index of 9.61 percent. The sharia financial sector with the lowest index is the capital market. The literacy index is only 0.02 percent, while the inclusion is 0.01 percent.

The Number and Quality of Human Resources

Table 2

Key Indicators

\begin{tabular}{|l|c|c|c|c|c|}
\hline \multicolumn{1}{|c|}{$\begin{array}{c}\text { Islamic Banking } \\
\text { Industry }\end{array}$} & $\begin{array}{c}\text { Nu. of } \\
\text { Institutions }\end{array}$ & $\begin{array}{c}\text { Nu. of } \\
\text { Office }\end{array}$ & $\begin{array}{c}\text { Assets } \\
\text { in trillion } \\
\text { rupiah }\end{array}$ & $\begin{array}{c}\text { Financing } \\
\text { in trillion } \\
\text { rupiah }\end{array}$ & $\begin{array}{c}\text { Deposits } \\
\text { in trillion } \\
\text { rupiah }\end{array}$ \\
\hline $\begin{array}{l}\text { Islamic Commercial } \\
\text { Banks }\end{array}$ & 13 & 1,825 & 288.02 & 189.79 & 238.22 \\
\hline $\begin{array}{l}\text { Islamic Business } \\
\text { Units }\end{array}$ & 21 & 344 & 136.15 & 95.91 & 96.49 \\
\hline Islamic Rural Banks & 167 & 441 & 10.84 & 7.76 & 6.99 \\
\hline \multicolumn{1}{|c|}{ Total } & $\mathbf{2 0 1}$ & $\mathbf{2 , 6 1 0}$ & $\mathbf{4 3 5 . 0 2}$ & $\mathbf{2 9 1 . 1 8}$ & $\mathbf{3 4 1 . 7 1}$ \\
\hline
\end{tabular}

The table 2 above shows the number of Islamic banks, sharia business units and BPRS that have been established in Indonesia to date. The birth of Islamic banks has encouraged other sharia financial industry sectors such as academic institutions, hospitals and communities that care about the development of the Islamic finance industry. For example, there are 13 Islamic banks with assets of 288.02 trillion rupiah. Government support is also increasingly seen to strengthen the existence of Islamic banking, especially with the issuance of Law Number 21 of 2008 concerning Islamic Banking and in 2015 the government has also established a National Islamic Finance Committee (KNKS).

However, Islamic banks must also concentrate on improving the bank's internal quality. Internal bank factors include the character and capacity of the bank's human resources as well as the customer's capacity and character. Factors in human resource capacity are so influential on the high level of problematic financing.

Limited capital is also one of the obstacles why the market share of Islamic banking in Indonesia is still small. As understood, of the 34 players in the Islamic banking industry 13 are sharia commercial banks and as many as 21 are sharia business units. What is the distribution of capital of BUS and UUS. Of the 13 sharia commercial banks, only Bank Syariah Mandiri (BSM) entered the bank with a capital category of up to Rp.30 trillion. While seven banks such as BTPN Syariah, BNI Syariah, BCA Syariah, Aceh Syariah, Mega Syariah, BRI Syariah, Muamalat were included in the capital category of Rp 1 trillion to Rp 5 trillion. Meanwhile, Maybank, Victoria, Bukopin Syariah, BJB Syariah and Panin Dubai have capital below Rp 1 trillion.

This is a fact that illustrates the current size of Islamic commercial bank capital in Indonesia. Then what about the capital of sharia business units. At present there are 21 sharia business units (UUS). Of the 21 sharia business units, 
the majority are owned by regional governments (BPD). On average 15 BPDs currently have capital under Rp. 1 trillion. While the number of workers can be seen in the table below.

Table 3

Development of Total Assets and Sharia Banking Workforce in Billion IDR

\begin{tabular}{|l|r|r|r|r|}
\hline \multicolumn{1}{|c|}{ Indicator } & $\mathbf{2 0 1 4}$ & \multicolumn{1}{|c|}{$\mathbf{2 0 1 5}$} & \multicolumn{1}{|c|}{$\mathbf{2 0 1 6}$} & \multicolumn{1}{|c|}{$\mathbf{2 0 1 7}$} \\
\hline Shariah Commercial Bank & & & & \\
$\checkmark$ Total Assets & 204.961 & 213.423 & 254.184 & 288.027 \\
$\checkmark$ Number of Employess & 41.393 & 51.413 & 51.110 & 51.068 \\
\hline Shariah Business Unit & & & & \\
$\checkmark$ Total Assets & 67.383 & 82.839 & 102.320 & 136.154 \\
$\checkmark$ Number of Employess & 4.425 & 4.403 & 4.487 & 4.678 \\
\hline Total Assets BUS and UUS & $\mathbf{2 7 2 . 3 4 3}$ & $\mathbf{2 9 6 . 2 6 2}$ & $\mathbf{3 5 6 . 5 0 4}$ & $\mathbf{4 2 4 . 1 8 1}$ \\
Total Number of Employees & $\mathbf{4 5 . 8 1 8}$ & $\mathbf{5 5 . 8 1 6}$ & $\mathbf{5 5 . 5 9 7}$ & $\mathbf{5 5 . 7 4 6}$ \\
\hline
\end{tabular}

Based on the table 3 above, it can be seen that the assets of Islamic banking have increased from year to year, in addition to that there has also been an increase in the number of workers. Like a common problem that occurs in the workforce in the banking sector in Indonesia, namely the lack of knowledge about the basic foundation of Islamic banking.

\section{CONCLUSION}

In conclusion why the Islamic banking market in Indonesia is still smaller because there are several factors that influence it such as Islamic banking regulations, Islamic banking inclusion and literacy are still low from conventional banks, Islamic banking still does not have sufficient capital, and the number and quality of Human Resources (HR) that are inadequate. This is probably a lesson learnt from past experience where many financial researchers argues for a more dicipline and well-regulated banking and financial system.

\section{REFERENCES}

Abdullah, Atikullah. 2017. A Comparison Between Malaysia And Indonesia In Islamic Banking Industry, Research Journal of Business and Management (RJBM). ISSN: 2148-6689, http://www.pressacademia.org/journals/rjbm, Volume: 4 Issue: 32017.

Abubakar, Lastuti and Handayani, Tri. 2017. Percepatan Pertumbuhan Perbankan Syariah Melalui Implementasi Tata Kelola Syariah. Jurnal Law and Justice Vol. 2 No. 2 Oktober 2017.

Alhamid, Thalha. 2019. Perkembangan Perbankan Syariah (2009-2018) Di Indonesia Dan Sumber Daya Manusia Nya.

Barmana, Muhamad Andira. Peningkatan MSS (Market Share Of Sharia) Dalam Menghadapi MEA (Masyarakat Ekonomi Asean) 2015 Melalui Im (Islamic Microfinance ) Dan IB (Islamic Banking) di Indonesia. 
Financial Services Authority. 2015. Accelerating Economic Growth Through a Contributive, Stable and Inclusive Financial Services Sector.

Financial Services Authority. 2017. Snapshot Of Indonesia Islamic Banking Development

Financial Services Authority. 2018. Republic of Indonesia Banking Licensing and Information Department, Jakarta.

Hakiim, Ningsukma and Rafsanjani, Haqiqi. 2016. Pengaruh Internal Capital Adequency Ratio (CAR), Financing To Deposit Ratio (FDR),Dan Biaya Operasional Per Pendapatan Operasional (BOPO) Dalam Peningkatan Profitabilitas Industri Bank Syariah Di Indonesia. Jurnal Aplikasi Manajemen Vol.14 No.1 Maret 2016.

Hamzah, Maulana. 2008. Pengembangan Perbankan Syariah Secara Objektif dan Rasional dengan Pendekatan Mekanisme Pasar. Jurnal Ekonomi Islam, Vol. II, No. 1, Juli 2008.

Nengsih, Novia. 2015. Peran Perbankan Syariah Dalam Mengimplementasikan Keuangan Inklusif Di Indonesia. Etikonomi Volume 14 (2), Oktober 2015 PISSN: 1412-8969; E-ISSN: 2461-0771 Halaman 221-240.

Otoritas Jasa Keuangan. 2015. Roadmap Perbankan Syariah Indonesia 20152019. Departemen Perbankan Syariah.

Otoritas Jasa Keuangan. 2016. Survei Nasional Literasi Dan Inklusi Keuangan.

Otoritas Jasa Keuangan. 2017. Siaran Pers Market Share Keuangan Syariah Capai 8 Persen. OJK Gelar Keuangan Syariah Fair Di Cibinong Bogor.

Purboastuti, Nurani and Anwar, Nurul and Suryahani, Irma. 2015. Pengaruh Indikator Utama Perbankan Terhadap Pangsa Pasar Perbankan Syariah. JEJAK: Jurnal Ekonomi dan Kebijakan, Vol.8, No.1, 2015.

Rahman, Aulia. 2016. Analisis Faktor-Faktor Yang Mempengaruhi Market Share Bank Syariah.

Saputra, Bambang. 2014. Faktor-Faktor Keuangan Yang Mempengaruhi Market Share Perbankan Syariah Di Indonesia. Akuntabilitas:Jurnal Ilmu Akuntansi Vol.7 No. 2, hal: 123-131, Agustus 2014.

Satibi, Elsa and Utami, Wiwik and Nugroho, Lucky, A Comparison Of Sharia Banks And Conventional Banks In Terms Of Efficiency, Asset Quality And Stability In Indonesia For The Period 2008-2016, International Journal of Commerce and Finance, Vol. 4, Issue 1, 2018, 134-149.

Shaffer, S. 1993. Bank Cempetition in Concentrated Markets. Federal Reserve Bank of Philadelphia Business Review, pp.3-16.

Sholikhah, Z. et al. 2017. Determinant of the Equity Based Financing Volume: A Case of Islamic Banks in Indonesia. Research Journal of Finance and Accounting, Vol.8, No.1, pp.30-39.

Siddiqi, M. N. 1985. Partnership and Profit-Sharing in Islamic Law. Leicester: The Islamic Foundation.

Siddiqui, S. H. 2002. Islamic Banking: True Modes of Financing. Journal of Islamic Banking \& Finance, vol. 19, no. 1, pp. 11- 24.

Siregar, M.E. and Ilyas N. 2011. Recent Developments in Islamic Banking in Indonesia. Proceedings of the Fifth Harvard University Forum on Islamic Finance. Islamic Finance: Dynamics and Development. Cambridge, Massachusetts. Center for Middle Eastern Studies, pp. 189196 
Sobol, I. 2016. Development Of Islamic Banking In Indonesia. Research Papers Of Wroctaw University Of Economics. Asian Economies in the Context of Globalization, Wroclaw: Publishing House of Wrocław University of Economics.

Yundi, Nisa Friskana and Sudarsono, Heri. 2018. Pengaruh Kinerja Keuangan Terhadap Return On Ssset (ROA) Bank Syariah Di Indonesia. Al-Amwal: Jurnal Kajian Ekonomi dan Perbankan Syariah. Vol.10 No.1 2018. DOI: 10.24235/amwal.v10i1.2759 